\title{
PELATIHAN DAN SOSIALISASI TEKNOLOGI PEMETAAN DALAM MITIGASI BENCANA BANJIR KOTA PANGKALPINANG
}

\section{TRAINING AND SOCIALIZATION OF MAPPING TECHNOLOGY IN FLOOD DISASTER MITIGATION AT PANGKALPINANG CITY}

\author{
Irvani $^{1)^{*}}$, EPSB Taman Tono ${ }^{2)}$, Janiar Pitulima ${ }^{3)}$ \\ 1)* Fakultas Teknik, Universitas Bangka Belitung, email: bujangbabel@yahoo.co.id \\ ${ }^{2)}$ Fakultas Teknik, Universitas Bangka Belitung, email: tamantono1969@gmail.com \\ ${ }^{3)}$ Fakultas Teknik, Universitas Bangka Belitung, email: janiar75@yahoo.com
}

\begin{abstract}
ABSTRAK
Kota Pangkalpinang memiliki topografi relatif rendah dan berbatasan dengan laut di bagian timur. Pendangkalan aliran sungai, serta alih fungsi lahan menyebabkan bencana banjir pada musim hujan. Berdasarkan permasalahan dibutuhkan peningkatan penguasaan teknologi pemetaan bagi aparatur kecamatan dan kelurahan, pembuatan peta banjir, dan mensosialisasikannya kepada kalangan pelajar. Program dimulai dengan survey pengumpulan data koordinat banjir, diskusi kelompok terarah dan pelatihan pembuatan peta, dan sosialisasi hasil. Hasil program pengabdian telah meningkatkan kapasitas para aparatur kecamatan dan kelurahan dalam penguasaan teknologi pemetaan. Pada peta banjir dan genangan air Kota Pangkalpinang menunjukkan pola sebaran banjir terdapat pada morfologi dataran rendah disepanjang aliran Sungai Rangkui. Pelajar dan mahasiswa peserta sosialisasi mitigasi bencana banjir mampu memahami materi secara optimal. Keseluruhan hasil program pengabdian secara signifikan memberikan sumbangsih dalam implemetasi teknologi pemetaan untuk mitigasi bencana banjir.
\end{abstract}

Kata Kunci: Banjir, Mitigasi, Pemetaan, Pelatihan, Sosialisasi

\section{ABSTRACT}

Pangkalpinang City has a relatively low topography and bordered by the sea in the east. the stream siltation and land-use change cause floods during the rainy season. Based on the problem, it is needed to improve the mastery of mapping technology for district and village apparatus, making flood maps, and disseminating them to students. The program starts with collecting flood coordinate data, focus group discussions and map-making training, and socialization the result. the program has increased the capacity of the district and village apparatus in the mastery of mapping technology. On the map of floods and puddles of Pangkalpinang City shows the flood pattern distribution found in the lowland morphology along the Rangkui River. Students and scholars participating in the flood disaster mitigation socialization understood the material optimally. The overall results of the community service program significantly contributed to the implementation of mapping technology in flood mitigation.

Keywords: Flood, Mitigation, Mapping, Training, Socialization

\section{PENDAHULUAN}

Pada tahun 2013-2020 terjadi beberapa kali bencana banjir di Kota Pangkalpinang yang merupakan Ibu Kota Propinsi Kepulauan Bangka Belitung. Banjir tersebut menimbulkan korban dalam jumlah ribuan jiwa mengungsi, dan ratusan unit rumah terendam banjir. Hampir setiap tahun terjadi bencana banjir dan genangan air dengan frekuensi satu sampai enam kali. Oleh karena itu perlu dilakukan penanganan untuk menimalkan resiko kerugian yang 
ditimbulkan oleh bancana banjir. BNPB [1] mendefinisikan bencana sebagai peristiwa atau rangkaian peristiwa yang mengancam dan mengganggu kehidupan dan penghidupan masyarakat yang disebabkan oleh faktor alam dan atau faktor non alam maupun faktor manusia sehingga mengakibatkan timbulnya korban jiwa, kerusakan lingkungan, kerugian harta benda dan dampak psikologis. Dampak kejadian bencana alam tersebut sangat merugikan masyarakat [2].

Pada Tahun 2011 nilai indeks rawan bencana Kota Pangkalpinang tergolong tinggi, dan paling tinggi di Propinsi Kepulauan Bangka Belitung, dengan indeks rawan bencana banjir masuk pada kategori kelas tinggi pula [1]. Resiko sosial Kota Pangkalpinang pada Tahun 2016 akibat bencana banjir masuk pada kategori sedang sebanyak 32.254 jiwa dan kategori tinggi 2.702 jiwa, resiko fisik masuk kategori tinggi sebesar 2.210.769 juta, resiko bencana banjir terhadap sektor ekonomi masuk kategori sedang sebesar 1.204 juta dan tinggi sebesar 9.070 juta, serta besar resiko banjir terhadap lingkungan masuk kategori sedang seluas 320 ha dan kategori tinggi 341 ha [3]. Kejadian bencana banjir dapat disebabkan oleh kondisi alam yang statis seperti geografis, topografis, dan geometri alur sungai [3]. Perubahan tata guna lahan banyak berpengaruh terhadap bencana banjir [4], karena sangat mempengaruhi aliran air permukaan [5].

Berdasarkan data dari BNPB [6], fluktuasi frekuensi bencana banjir di Kota
Pangkalpinang dengan bentuk kerugian berupa korban jiwa dan terendamnya kawasan permukiman yang besarnya bergantung kepada intensitas banjir. Bencana banjir pada Tahun 2013, 2016 dan 2018 telah menimbulkan angka ungsian penduduk yang besar dalam jumlah ribuan, dan tingkat ungsian terbesar pada Tahun 2016 mencapai 3.454 jiwa, dengan kerusakan rumah mencapai puluhan unit. Data terbaru bencana banjir Kota Pangkalpinang pada Tahun 2019 memiliki frekuensi kejadian banjir yang tinggi dengan tingkat ungsian mencapai 547 jiwa, dan sebanyak 72 rumah terendam. Banjir di Kota Pangkalpinang setiap tahun terjadi terutama di Kelurahan Bukit Intan dan Jalan Balai.

Morfologi Kota Pangkalpinang didominasi oleh dataran rendah dan dataran rendah bergelombang dengan kemiringan 0$15 \%$, oleh [7] disebut peneplain seperti umumnya Pulau Bangka. Tipe pasang surut harian bersifat tunggal, dengan satu kali pasang dan satu kali surut [8]. Kota Pangkalpinang dan sekitarnya memiliki frekuensi curah hujan kategori ekstrim rendah [9], dengan kondisi imbangan air masuk kategori buruk [10].

Luasan wilayah potensi banjir Kota Pangkalpinang sebesar 8.266,7 ha [11]. Tinggi muka air banjir (luapan) yang dipengaruhi pasang surut air laut diestimasikan dapat mencapai setinggi 1,90 m [8]. Pada wilayah permukiman yang padat aliran air menjadi lambat kala hujan, 
diperparah penimbunan daerah resapan dan genangan air seperti rawa untuk permukiman berdampak pada meningkatkan debit banjir [12], termasuk aktivitas pertambangan timah rakyat di sekitar Kota Pangkalpinang menyebabkan pendangkalan sungai [12], [13].

Langkah pencegahan untuk mengurangi resiko bencana alam dilakukan melalui kegiatan mitigasi bencana alam [2]. Mengatasi bencana banjir memerlukan partisipasi masyarakat, serta koordinasi antar pihak dalam komunitas, pemangku kepentingan, pemerintah serta LSM dan NPO [14]. Contoh teknis sederhana lain yaitu melalui penerapan lubang resapan biopori juga dapat menanggulangi banjir [15]. Program implementasi yang dapat dilakukan untuk tujuan tersebut dengan meningkatkan kapasitas aparatur kecamatan dan kelurahan dalam teknologi mitigasi bencana banjir, dan melakukan sosialisasi tanggap darurat banjir bagi kalangan pelajar dan mahasiswa yang berdomisili di Kota Pangkalpinang dalam upaya mengurangi dampak kerugian, serta meningkatkan kesiap siagaan terhadap bencana banjir. Undang-Undang No. 24 [16] dapat menjadi dasar hukum uatama dalam upaya penanggulangan bencana banjir tersebut.

\section{METODE}

Pelaksanaan program Pelatihan dan Sosialisasi Teknologi Pemetaan dalam Mitigasi Bencana Banjir Kota Pangkalpinang bagi aparatur kecamatan dan kelurahan, serta kalangan pelajar SMA dan mahasiswa merupakan keberlanjutan dari hasil penelitian banjir yang telah dilakukan di Kota Pangkalpinang yang merupakan wilayah rawan bencana banjir dan sekaligus merupakan Ibukota Provinsi Kepulauan Bangka Belitung. Adapun pelaksanaan program terbagi menjadi 3 (tiga) tahap, yaitu tahap persiapan, pelaksanaan dan evaluasi program.

Tahap persiapan dalam pelaksanaan program terdiri dari:

1. Melakukan koordinasi dengan Aparatur kecamatan dan kelurahan, beserta mitra BNPB/BPBD Kepulauan Bangka Belitung dan Kota Pangkalpinang.

2. Melakukan survey pengambilan koordinat lokasi yang potensial bencana banjir dengan menggunakan GPS (Global Possitioning System).

Pelaksanaan program yang ditujukan kepada para aparatur kecamatan dan kelurahan dalam upaya peningkatan kapasitas penguasaan teknologi pemetaan dalam mitigasi bencana banjir, serta sosialisasi hasilnya kepada kalangan pelajar SMA dan mahasiswa.

Pelaksanaan program meliputi:

1. Diskusi Kelompok Terarah (FGD) dan pelatihan pengolahan data banjir menggunakan software pemetaan (open source), Software QGis (opensource) bagi aparatur kecamatan dan kelurahan serta para sukarelawan. 
2. Sosialisasi mitigasi banjir kepada kalangan pelajar dan mahasiswa yang melibatkan mitra dari BPBD Kepulauan Bangka Belitung dan BPBD Kota Pangkalpinang.

Pada tahap akhir dilakukan evaluasi program pengabdian. Hasil evalusi untuk mengukur penguasaan pengoperasian teknologi pemetaan dalam mitigasi banjir bagi kalangan aparatur kecamatan dan kelurahan. Adapun evaluasi program terhadap kalangan pelajar dan mahasiswa adalah untuk mengukur pemahaman pelajar dan mahasiswa terhadap pengetahuan mitigasi bencana banjir yang diberikan.

\section{HASIL DAN PEMBAHASAN}

Persiapan Program dimulai melalui koordinasi Tim Pengabdian dengan pihak Kecamatan Taman Sari, Kecamatan Rangkui dan Kecamatan Bukit Intan dan pihak mitra, BPBD Provinsi Kepulauan Bangka Belitung dan BPBD Kota Pangkalpinang. Kecamatan Taman Sari, Kecamatan Rangkui dan Kecamatan Bukit intan terpilih sebagai lokasi pengabdian, karena memiliki daerah rawan banjir yang tergolong luas. Kelurahan Gedung Nasional, Kelurahan Rawa Bangun, Kelurahan Pasir Putih dan Kelurahan Bintang memiliki wilayah terdampak banjir paling luas. Secara khusus untuk bencana banjir Tahun 2016 terdapat banyak wilayah yang terendam banjir dengan kerugian moril dan materil yang tergolong sangat besar.

Setelah dilakukan koordinasi, dilanjutkan dengan pengambilan data koordinat daerah yang pernah terdampak banjir serta koordinat lokasi yang diperkirakan menjadi penyebab banjir dengan menggunakan GPS Handheld (Gambar 1.a). Dalam pengambilan data GPS tersebut sebagian besar melibatkan tenaga pembantu lapangan sebanyak tiga orang yang merupakan mahasiswa tingkat akhir Universitas Bangka Belitung, dengan lama pengambilan data selama empat hari.

Terhimpun sebanyak 42 titik batas banjir atau titik genangan air utama, 10 titik banjir yang merepresentasikan tinggi luapan air sewaktu banjir banjir/genangan air, serta 10 titik posko tanggap darurat banjir. Titik batas banjir atau genangan air meliputi batas banjir besar yang pernah melanda Kota Pangkalpinang pada Tahun 2016, disertai banjir atau genangan air tahunan pada musim hujan bersifat lokal yang terjadi setiap hujan besar turun di Kota Pangkalpinang dan sekitarnya sampai dengan Tahun 2019.

Setelah semua data banjir terhimpun, selanjutnya dilakukan diskusi kelompok terarah (FGD) dan pelatihan pengolahan data banjir menggunakan Software Pemetaan (open source) QGis yang dilakukan selama 3 (tiga) hari secara bergantian yang bertempat di Kantor Kecamatan Taman Sari, Kecamatan Rangkui dan Kecamatan bukit Intan, dengan peserta berasal dari utusan setiap kecamatan dan kelurahan (Gambar 1.b, 1.c dan 1.d). Setiap utusan kecamatan dan kelurahan membawa laptop untuk mengikuti FGD dan pelatihan pengolahan data banjir. Pada tahap ini diberikan paparan materi singkat tentang pengambilan data koordinat 
dengan menggunakan GPS dan pengolahan laptop peserta, dilakukan pengolahan data datanya menggunakan Software QGis. koordinat wilayah banjir yang telah Setelah instalasi Software QGis pada setiap dihimpun.

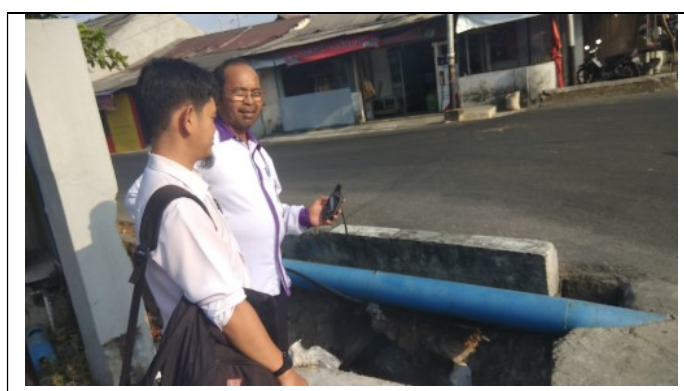

(a)

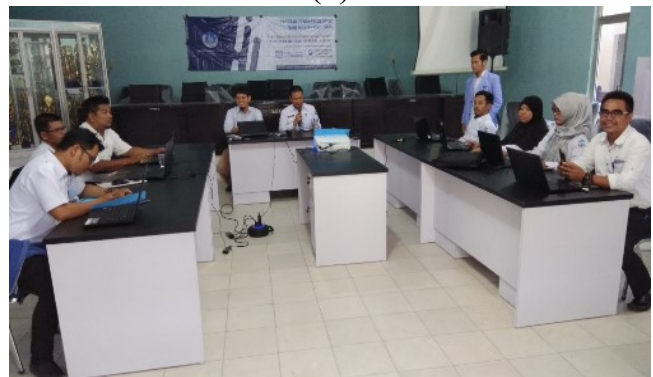

(c)

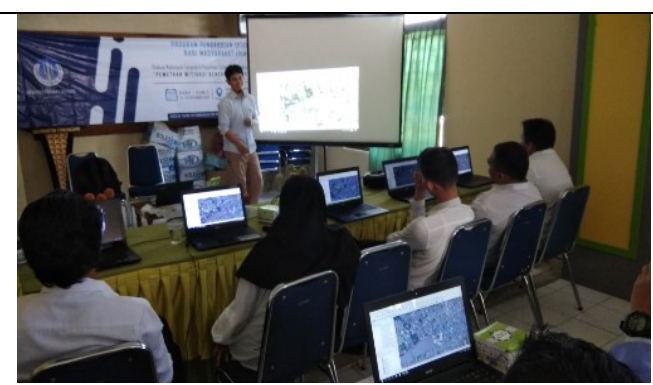

(b)

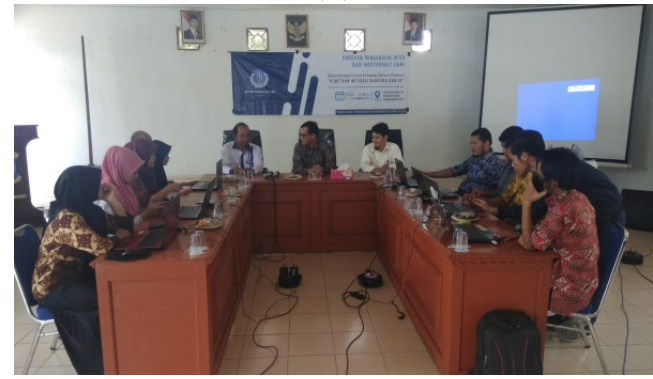

(d)

Gambar 1. Kegiatan: (a) Pengambilan data koordinat banjir, (a, b dan c) Diskusi kelompok terarah (FGD) dan pelatihan pengolahan data banjir di Kecamatan Taman Sari, Kecamatan Rangkui dan Kecamatan Bukit Intan

Setiap peserta FGD dan pelatihan berlatih melalui panduan tiga orang Tim Pengabdian yang dibantu oleh sebanyak dua orang mahasiswa untuk mengolah dan menyajikan data koordinat banjir menjadi Peta Banjir dan Genangan Air Kota Pangkalpinang. Dalam penggambaran peta banjir dan genangan air tersebut dilakukan klarifikasi oleh setiap perwakilan kelurahan dan kecamatan yang lebih mengenal wilayah kerjanya masing-masing. Hasilnya berupa batas wilayah banjir dan genangan air, lokasi penyebab banjir, dan tempat-tempat pengungsian sementara sewaktu banjir yang tidak terdapat data koordinatnya sewaktu survey lapangan dilakukan.
Citra Google earth beresolusi tinggi dan peta RBI skala 1:25.000 digunakan untuk mempermudah proses klarifikasi tersebut. Peta Wilayah Banjir dan Genangan Air Kota Pangkalpinang yang telah selesai difinalisasikan kemudian dibuatkan lay out peta yang telah dihasilkan sebagaimana diilustrasikan pada Gambar 2.

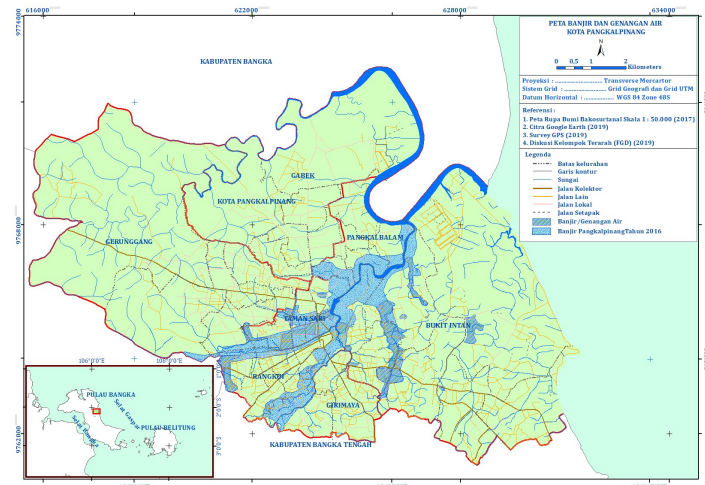

Gambar 2. Peta bencana banjir dan genangan air Kota Pangkalpinang 
Pada hari Pertama FGD dan pelatihan pengolahan data banjir dilakukan di Kecamatan Taman Sari dengan perwakilan sebanyak delapan orang peserta yang merupakan utusan kecamatan dan kelurahankelurahan yang dinaungi. Tercatat dan tergambarkan Kelurahan Gedung Nasional, Kelurahan Rawa Bangun dan Kelurahan Batin Tikal memiliki genangan banjir yang paling luas dan terdampak parah dan cukup parah setiap banjir tahunan di Kecamatan Taman Sari. Selanjutnya pada hari kedua dilakukan FGD dan pelatihan di Kecamatan Rangkui, dengan jumlah peserta cukup banyak, yaitu 12 orang, yang terdiri dari utusan kecamatan dan setiap kelurahan.

Kecamatan Taman Sari memiliki jumlah kelurahan yang paling banyak di Kota Pangkalpinang dibandingkan dua kecamatan lain yang menjadi tempat pengabdian. Tergambarkan pada Peta Banjir dan Genangan Air, Kelurahan Pasir Putih dan Kelurahan Bintang memiliki wilayah genangan banjir yang paling luas dan terdampak parah sewaktu banjir yang terjadi setiap tahun.

Pada hari ketiga kegiatan FGD dan pelatihan dilakukan di Kecamatan Bukit Intan yang dihadiri sebanyak 10 peserta utusan kecamatan dan kelurahan. Hasil gambar pada peta banjir dan genangan air menunjukkan Kelurahan Pasir Putih, Kelurahan Semabung Lama dan Kelurahan Air Mawar memiliki genangan banjir yang luas dan terdampak cukup parah sewaktu banjir yang terjadi hampir setiap tahun. Pola sebaran daerah banjir dan genangan air Kota Pangkalpinang umumnya di sepanjang daerah dataran rendah aliran Sungai Rangkui yang mengalir di tengah kota, tersebar dari arah baratdaya dan selatan kota menuju ke arah timurlaut sampai memasuki aliran sungai utama yang masuk DAS Baturusa.

Faktor-faktor geogenik (alam) dan antropogenik (manusia) menjadi penyebab bencana banjir. Faktor-faktor geogenik penyebab terjadinya banjir antara lain berupa ketinggian topografi Kota Pangkalpinang tergolong rendah atau dekat dengan muka laut rata-rata (msl), volume air Sungai Rangkui dipengaruhi oleh pasang surut air laut, sedimentasi yang tinggi, serta faktor curah hujan dan pasang laut tinggi pada waktu tertentu setiap tahun.

Berbagai faktor yang berhubungan dengan aktivitas manusia (antropogenik) sebagai penyebab atau pemicu bencana banjir Kota Pangkalpinang berupa alih fungsi hutan dan rawa untuk pembangunan berbagai infrastruktur dan permukiman yang menyebabkan daerah resapan air berkurang secara signifikan, penyempitan aliran Sungai Rangkui akibat pembangunan permukiman pada daerah sempadan sungai, penyumbatan drainase perkotaan oleh sampah, serta pendangkalan Sungai Rangkui secara masif oleh sedimentasi yang sangat tinggi akibat penambangan bijih timah illegal pada bagian hulu Sungai Rangkui yang secara 
administrasi masuk daerah Kabupaten Bangka Tengah dan Kabupaten Bangka.

Pada sisi lain, kegiatan FGD dan pelatihan telah meningkatkan kapasitas para peserta dari kalangan aparatur pemerintahan kecamatan dan kelurahan dalam penguasaan teknologi pemetaan. Semua peserta sebelum pelatihan diberikan belum ada yang menguasai teknologi pemetaan $(0 \%$ penguasaan), dan setelah pelatihan diberikan semua peserta (100\%) memiliki wawasan dan mampu mengoperasikan dalam tahap dasar teknologi pemetaan. Bekal pengetahuan dan penguasaan teknologi pemetaan yang telah diperoleh peserta dapat diaplikasikan untuk pemetaan berbagai tematik kependudukan, sosial dan ekonomi masyarakat di masa yang akan datang.

Setelah diskusi kelompok terarah (FGD) dan pelatihan selesai dilakukan, selanjutnya dilakukan kegiatan sosialisasi mitigasi bencana banjir yang bertempat di Gedung Aula Kecamatan Rangkui. Sosialisasi diisi oleh para narasumber yang berasal dari BPBD Provinsi Kepulauan Bangka Belitung dan BPBD Kota Pangkalpinang dan Tim Pengabdian Universitas Bangka Belitung. Peserta sosialisasi berasal dari berbagai Sekolah Tingkat Menegah Atas (SLTA) atau sederajat, dan mahasiswa dari berbagai perguruan tinggi dari Kota Pangkalpinang sebanyak 60 peserta pelajar dan mahasiswa (Gambar 3).

Adapun rangkaian kegiatan pada sosialisasi berupa pra-test (sebelum pemberian materi), pemberian materi dan post-test (setelah pemberian materi). Paparan materi diberikan secara bergantian oleh para pemateri. Detail materi yang diberikan selama sosialisasi mitigasi bencana banjir bagi kalangan pelajar dan mahasiswa ditabulasikan pada Tabel 1.

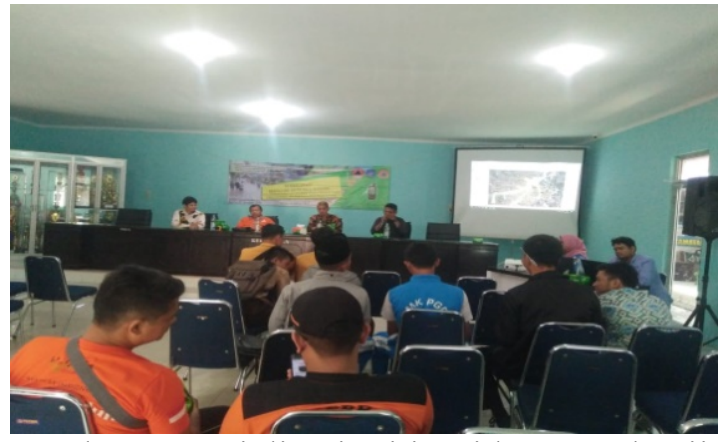

Gambar 3. Sosialisasi mitigasi bencana banjir

Total terdapat sebanyak empat orang pemateri yang telah memberikan materi secara bergantian dengan tema yang berhubungan erat dengan mitigasi bencana alam dan bencana banjir bagi kalangan pelajar dan mahasiswa. Setiap pemateri memberikan pengayaan pengetahuan wawasan bencana banjir, penggunaan aplikasi berbasis android, serta teknologi pemetaan dalam mitigasi bencana banjir. Pemateri pertama memaparkan gambaran umum keseluruhan potensi bencana alam yang terdapat di Propinsi Kepulauan Bangka Belitung.

Pemateri kedua memberikan pengayaan materi tentang kondisi dan upaya-upaya mitigasi bencana banjir di Kota Pangkalpinang. Pemateri ketiga mengajarkan praktek pemanfaatan aplikasi berbasis android dalam penentuan resiko bencana yang terdapat pada suatu tempat. Adapun 
pemateri keempat yang sekaligus merupakan tim pengabdian Universitas Bangka Belitung memberikan wawasan teknologi-teknologi dalam pemetaan bencana banjir, dan sekaligus memberikan ulasan Peta Bencana Banjir dan Genangan Air Kota Pangkalpinang yang telah dihasilkan dari rangkaian tahapan kegiatan pengabdian sebelumnya.

Evaluasi dilakukan untuk mengukur tingkat keberhasilan kegiatan sosialisasi. Evaluasi ditinjau berdasarkan hasil pre test dan post test, termasuk bentuk saran dan kritik yang membangun dari peserta. Melalui 10 pertanyaan yang dijawab secara singkat selama 10 menit, tingkat pemahaman peserta sosialisasi diukur, dan menjadi indikator utama kegiatan terlaksana sesuai dengan tujuan yang diharapkan. Berdasarkan hasil pre test dan post test sebagaimana diilustrasikan oleh grafik pada Gambar 4, secara umum menunjukkan peserta telah memiliki taraf tingkat pegetahuan yang memadai dan cukup memadai mengenai mitigasi bencana banjir. Peserta telah mendapatkan pengetahuan tersebut sebelumnya melalui berbagai materi perkuliahan, belajar di kelas dan sosialisasi mengenai bencana banjir yang telah dilakukan oleh berbagai pihak, bahkan diantaranya telah mengalami atau menjadi korban bencana banjir.

Tabel 1. Rekapitulasi materi yang diberikan para narasumber pada sosialisasi mitigasi bencana banjir

\begin{tabular}{|c|c|c|}
\hline No & Narasumber & Uraian Materi \\
\hline 1. & Pemateri 1 & $\begin{array}{l}\text { - Judul: Antisipasi Bencana Banjir di Propinsi Kepulauan } \\
\text { Bangka Belitung } \\
\text { - Dasar Hukum Undang-Undang No. } 24 \text { tahun } 2007 \\
\text { - Konsep penanggulangan bencana dan bahaya } \\
\text { - Antisipasi banjir, banjir rob, angin puting beliung, abrasi, } \\
\text { badai laut tropis, petir, dsb. } \\
\text { - Bencana dan mitigasi banjir Propinsi Kepulauan Bangka } \\
\text { Belitung Tahun 2016. }\end{array}$ \\
\hline 2. & Pemateri 2 & $\begin{array}{l}\text { - Judul : Tanggap Tangkas dan Tangguh Menghadapi Bencana } \\
\text { - Dasar Hukum Undang-Undang Nomor } 24 \text { Tahun } 2007 \\
\text { - Mitigasi (jenis, tujuan) } \\
\text { - Kenali banjir, tindakan mengurangi dampak akibat bencana } \\
\text { banjir, langkah pencegahan sebelum banjir, menghadapi } \\
\text { banjir, pasca banjir. }\end{array}$ \\
\hline 3. & Pemateri 3 & $\begin{array}{l}\text { - Materi aplikasi inarisk personal } \\
\text { - Instalasi aplikasi pada playstore untuk android } \\
\text { - Praktek aplikasi inarisk personal }\end{array}$ \\
\hline 4. & Tim Pengabdian & $\begin{array}{l}\text { - Judul : Penerapan Teknologi Pemetaan dan Sosialisasi } \\
\text { Mitigasi Bencana Banjir Kota Pangkalpinang. } \\
\text { - Pengenalan teknologi GPS dan satelit } \\
\text { - Pengenalan Teknologi Software QGis } \\
\text { - Penggambaran Peta menggunakan Software QGis } \\
\text { - Peta Banjir dan Genangan Air Kota Pangkalpinang } \\
\text { - Analisis banjir Kota Pangkalpinang }\end{array}$ \\
\hline
\end{tabular}




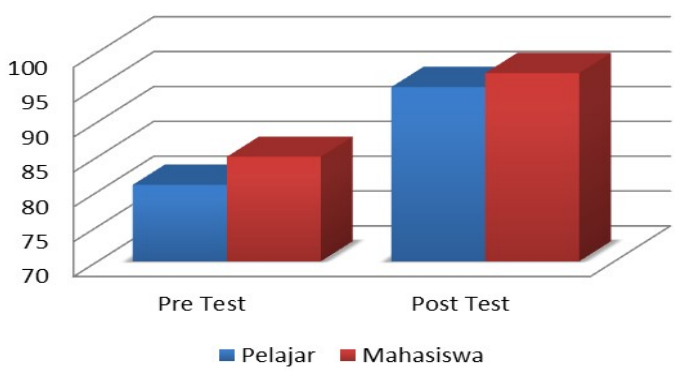

Gambar 4. Persentase tingkat pemahaman peserta sebelum dan sesudah mendapatkan pemaparan materi sosialisasi

Hasil pre test, bagi kalangan mahasiswa menunjukkan telah memiliki pemahaman bencana banjir rata-rata sebesar $85 \%$, atau telah memiliki pengetahuan yang memadai, dan bagi kalangan pelajar menunjukkan persentase rata-rata yang sedikit lebih rendah, yaitu sebesar $81 \%$. Setelah dilakukan sosialisasi oleh pemateri yang kompeten, dan praktik singkat menggunakan aplikasi banjir berbasiskan android, serta wawasan spasial Peta Sebaran Banjir dan Genangan Air Kota Pangkalpinang menunjukkan peningkatan pemahaman yang cukup signifikan mahasiswa dan pelajar peserta sosialisasi, secara berurutan sebesar $12 \%$ dan $14 \%$.

Pemahaman akhir yang didapat rata-rata mencapai $97 \%$ bagi kalangan mahasiswa dan 95\% untuk kalangan pelajar. Hasil evaluasi tersebut sangat menggembirakan tim pengabdian, dan menunjukkan bahwa sosialisasi yang diberikan mampu meningkatkan pengetahuan peserta dengan sangat baik.

\section{KESIMPULAN}

Berbagai kesimpulan yang dapat ditarik sebagai berikut :
1. Pelatihan pemanfaatan teknologi pemetaan bencana banjir mampu meningkatkan kapasitas aparatur pemerintah kecamatan dan kelurahan yang terdampak banjir di Kota Pangkalpinang dalam penguasaan teknologi pemetaan.

2. Berdasarkan peta tergambarkan pola banjir dan genangan air Kota Pangkalpinang umumnya terjadi pada daerah dataran rendah disepanjang aliran Sungai Rangkui yang memiliki arah relatif dari baratdaya dan selatan menuju ke arah timurlaut. Faktor antropogenik dan geogenik menjadi penyebab bencana banjir.

3. Kegiatan sosialisasi mitigasi bencana banjir bagi kalangan pelajar tingkat SLTA dan mahasiswa telah meningkatkan wawasan mitigasi bencana lebih optimal, dengan antusiasme yang tinggi selama kegiatan.

\section{UCAPAN TERIMAKASIH}

Penulis mengucapkan terima kasih kepada Universitas Bangka Belitung yang telah memberi dukungan financial dan administratif terhadap pengabdian IbM ini, mitra pengabdian BPBD Provinsi Kepulauan Bangka Belitung dan BPBD Kota Pangkalpinang, pihak Kecamatan Rangkui, Taman Sari dan Kecamatan Bukit Intan yang telah mefasilitasi, serta semua pihak yang telah membantu selama program pengabdian dilaksanakan. 


\section{REFERENSI}

[1] BNPB, (2011). Indeks Rawan Bencana Indonesia. Jakarta: Direktorat Pengurangan Risiko Bencana, Badan Nasional Penanggulangan Bencana.

[2] BNPB, (2010). Rencana Nasional Penanggulangan Bencana 2010-2014. Jakarta: Direktorat Pengurangan Risiko Bencana, Badan Nasional Penanggulangan Bencana.

[3] BNPB, (2016). Risiko Bencna Indonesia. Jakarta: Direktorat Pengurangan Risiko Bencana, Badan Nasional Penanggulangan Bencana.

[4] Rosyidie, A. 2013. Banjir: Fakta dan Dampaknya, Serta Pengaruh dari Perubahan Guna Lahan. Jurnal Perencanaan Wilayah dan Kota, 24(3), 241-249.

[5] Pertiwi, P. C., Hisyam, E. S. dan Yofianti, D. (2019). Analisis Pengaruh Perubahan Tata Guna Lahan Terhadap Jumlah Aliran Permukaan Pada Das Pompong Di Kabupaten Bangka. Prosiding SNPPM 2019, Pangkalpinang, 45-49.

[6] BNPB, (2019). diakses dari http://bnpb.cloud/dibi/xdibi list.

[7] Van Bemmelen, R. W. (1970). The Geology of Indonesia. General Geology Volume I A. The Hague, Netherland: Martinus Nijhoff.

[8] Ananditha, T. dan Hambali, R. (2015). Analisis Pengaruh Back Water (Air Balik) Terhadap Banjir Sungai Rangkui
Kota Pangkalpinang. Jurnal Fropil, 3(2), 131-141.

[9] Fadholi, A. dan Adzani, R. (2018). Analisis Frekuensi Curah Hujan Ekstrem Kepulauan Bangka Belitung Berbasis Data Climate Hazards Group Infra-Red Precipitation With Stations (CHIRPS). Jurnal Pendidikan Geografi, 18(1), 22-32.

[10] Sabri, F. dan Hambali, R. (2013). Kajian Imbangan Air Pulau Bangka. Jurnal Fropil, 1(2), 1-14.

[11] Kepmen PUPR Nomor 710/KPTS/M/ 2016 tentang Pola Pengelolaan Sumber Data Air Wilayah Sungai Bangka.

[12] Irvani dan Gunawan, I. (2015). Studi Pendahuluan Potensi Bencana Alam (Geo-Disater) di Pulau Bangka. Jurnal Promine, 2(2), 1-9.

[13] Yuliana, H. S. (2017). Analisis Dampak Pertambangan Timah Rakyat Terhadap Bencana Banjir. Jurnal Manajemen Bencana, 3(1), 57-73.

[14] Findayani, A. (2015). Kesiap Siagaan Masyarakat Dalam Penanggulangan Banjir di Kota Semarang. Jurnal Geografi, 12(1), 103-114.

[15] Apriani, W. dan Haris, V. T. (2019). IbM Sosialisasi Penerapan Lubang Resapan Biopori Bagi Masyarakat Di Lingkungan RW 06 Dan RW 18 Kelurahan Sidomulyo Barat Kota Pekanbaru. Jurnal Dinamisia, 3, 149155.

[16] UU No. 24 Tahun 2007 Tentang Penanggulangan Bencana. 